\title{
Risk Assessment of Genotoxic Effects of Artificial Food Colorants on V. Faba and A. cepa using DNA-RAPD Fingerprinting and Behavior of Mitotic Chromosomes
}

\author{
Abdel-Rahem Tawfeek Elrefaii and Marwa Gamal Ahmed
}

Genetics Department, Faculty of Agriculture, Minia University

Corresponding author: drelrefaii@mu.edu.eg

\begin{abstract}
Plant bioassays are quite sensitive and simple technique in comparison to animal bioassay to assess the genotoxicity and cytotoxicity of a chemical compound. A. cepa and $V$.faba have been widely accepted for evaluation of genotoxicity and the assay is well known and commonly used in many laboratories in good correlation with results from other established test systems. A. cepa has relatively large monocentric chromosomes and accepted as suitable test organism for the study of environmental mutagenesis. Also $V$. faba beans was used as indicator to determine genotoxic effect of synthetic dyes used as food additives. The mitotic index is one of the mitotic parameters, which reflects the genetic. control system of division and the existence of chromosomal aberrations in several organisms In the present work, the genotoxic effects of three food colorants on two types of living organisms i.e. (Allium cepa and Vicia faba) plants were studied. The three food colorants were (Ponceau 4R, Sunset yellow and Tartrazine). Each colorant was used in three concentrations $0.25 \%, 0.50 \%$ and $1.00 \%$. The results showed that all synthetic food colorants which used in the experiment decreased the mitotic indices in V.faba and A.cepa. Moreover the synthetic food colors disturbed the percentages of mitotic stages and the chromosomes behavior and configuration during the mitotic division. Also, the study compared the effects occurring at molecular levels in Allium cepa and Vicia faba exposed to colored food at $1 \%$ concentration aqueous solution. The qualitative modifications arising in random amplified polymorphic DNA (RAPD) profiles as a measure of DNA effects were compared with control. Results showed that treatments of the above test samples reflect changes in RAPD profiles. Changes in RAPD patterns included variation in band intensity, loss of normal bands and appearance of new bands compared with control. More over the ability of different primer for producing DNA fragment is varied from genome to other. The results indicated that DNA polymorphism.
\end{abstract}

Key words: DNA- RAPD, V. faba , A .cepa , Mitotic chromosomes, Food colorants

\section{Introduction}

The food coloring history dates back to early Egyptians and Romans civilizations, when people used saffron, various flowers, carrots, mulberries, beets, and so forth to put color to their foods (Feng $\boldsymbol{e t}$ al., 2012). Later during the middle of the nineteenth century, people had started using synthetic colorants in place of natural colorants. Since then the extensive use of synthetic food azo dyes $(-\mathrm{N}=\mathrm{N}-)$ has become very common due to increasing canned and fast food culture, despite their legislative ban. Food colorants only make food attractive to meet new consumer demand, since the visual aspect is considered to be an important factor for the selection of products by final consumers (Hashem et al., 2011).

Food colorants divide in to two types which they are natural food colorants and artificial food colorants. Natural food colorants are directly extracted and purified from natural sources like seeds, fruits, vegetables, leaves, insects, algae, etc. Natural colorants are not as iridescent, strong, or shelf-stable as synthetic colorants which can be mixed and matched to produce quite literally millions of colorants. Artificial dyes and pigments are derived from petroleum products and are intended to last for years and years (Kumar and Srivastava, 2011).

Plant bioassays have been validated in international collaborative studies under the United
Nations Environment Program (UNEP), World Health Organization (WHO), and US Environmental Protection Agency (US EPA) (Türkoğlu, 2009) and proved to be efficient tests for genotoxic monitoring of environmental pollutants Bolle et al., 2004). Many color additives had never been tested for toxicity or other adverse effects. According to the consumer advocacy group Center for Science in the Public Interest, artificial food coloring and food dyes present many risks to consumers. A report published by the center notes that many commonly used artificial food colorants have been found to cause damage to DNA, or genotoxicity, in more studies than they were found to be safe.

A comprehensive review of the genotoxicity of food colorants, drugs and cosmetic dyes was published by (Abdelmigid, 2009 and Montaser and Alkafafy, 2013). Adhvaryu and Shah (1979) reported that successful operation of cell division depends on programmed organization of many macromolecule synthesizing processes. Organisms used in mutagenesis testing should be selected using criteria that permit a realistic evaluation of the potential of a suspected mutagen to induce changes in genetic material such as structural and/or numerical modification of chromosomes resulting in chromosome aberrations (Matsumoto et al., 2006). $A$. cepa has relatively large monocentric chromosomes and accepted as suitable test organism for the study of 
environmental mutagenesis (Patra and Sharma, 2002). The percentage of dividing cells is defined as the mitotic index. The mitotic index is one of the mitotic parameters, which reflects the genetic control system of division and the existence of chromosomal aberrations in several organisms (Kaushik, 1996).

İlhan and Akı (2010) tested highly sensitive botanical tests of mutagenicity (Vicia faba L. root tip mitosis test, micronucleus test. The results consistently showed that mutation levels increased, depending on the dosage, in all plant groups. In addition, while micronucleus frequency significantly increased and mitotic indexes significantly decreased with the increasing dosages in Vicia faba L. and Allium cepa $L$. It was also detected that both foodcoloring agents had genotoxic potential on plants with different sensitivities and Vicia faba L. or Allium cepa $L$. plants are appropriate for mutagenicity studies.

Molecular markers allow a direct comparison of the effects of genotoxins at the DNA level. The explorations of random amplified polymorphic DNA (RAPD) as genetic markers have improved the detection of DNA alterations after the influence of many genotoxic agents Atienzar et al.( 2001). The objectives of this study have been to investigate the possibility of mutation changes in Allium cepa and Vicia faba treated with food colorants (Ponceau 4R (E124), Sunset yellow (E110) and Tartrazin(E102) ) using cytological examination and RAPD method, to determine whether the RAPD assay could detect how food colorants'- induced DNA effects in plant DNA, and to assess how these endpoints compare in terms of detection of toxicity.

\section{Material and Methods}

\section{Food Colorants:}

In the present work, the genotoxic effects of three food colorants were examined on two types of living organisms (Allium cepa and Vicia faba) plants. The three food colorants were Ponceau 4R, Sunset yellow and Tartrazine. Each colorant was used in three concentrations $0.25 \%, 0.50 \%$ and $1.00 \%$.

\section{Ponceaur 4R:}

It is a synthetic colorant and a strawberry red azo dye which can be used in a variety of food products. It is denoted by E Number as E124 (FDA, 2008). Its chemical name is 1- (4-sulpho-1-napthylazo)- 2napthol- 6,8-disulphonic acid, trisodium salt $\left(\mathrm{C}_{20} \mathrm{H}_{11} \mathrm{~N}_{2} \mathrm{Na}_{3} \mathrm{O}_{10} \mathrm{~S}_{3}\right)$. And its IUPAC name is trisodium (8Z)-7-oxo-8-[(4-sulfonatonaphthalen-1-yl) hydrazinylidene] naphthalene-1,3-disulfonate.

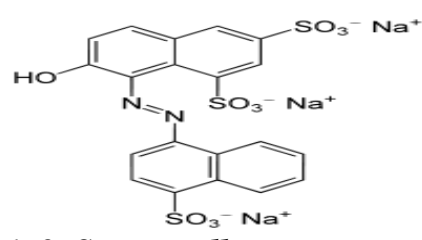

1. 2. Sunset yellow:
Sunset Yellow FCF is known as Yellow 6. It is a synthetic colorant and orange azo dye which can be used in food, cosmetics, and drugs (FDA, 2009). For example, it is used in candy, desserts, snacks, sauces, and preserved fruits (Abbey et al., 2013). It is denoted by E Number as E110 (Wood, 2004). And its IUPAC name is Disodium 6-hydroxy5-[(4-sulfophenyl) azo]-2-naphthalenesulfonate.<smiles>CS(=O)(=O)c1ccc(/N=N/c2c(O)ccc3cc(S(C)(=O)=O)ccc23)cc1</smiles>

\section{3. Tartrazine:}

Tartrazine is known as FD\&C (Yellow 5). It is a synthetic lemon yellow azo dye primarily used as a food coloring. It is denoted as E102 (FDA, 2009). Its chemical name is trisodium 1-(4-sulfonatophenyl)4-(4-sulfonatophenylazo)-5-pyrazolone-3carboxylate). And its IUPAC name is Trisodium 5hydroxy-1-(4-sulfonatophenyl)-4-[(E)(4sulfonatophenyl)diazenyl]-1H-pyrazole-3carboxylate.

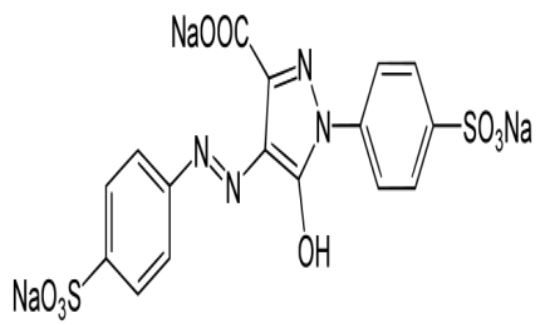

\section{Living Organisms:}

In this experiment two plant species were used to study the genotoxic effect the three food colorants: Ponceau 4R, Sunset yellow and Tartrazine. One of them Allium cepa as monocot plant and the other species was Vicia faba as dicot plant.

\section{Cytological Experiments:}

Bulbs of Allium cepa (Giza 6) in the same size and its weight about 30-35 g, were denuded by removing the loose outer scales and scraped so that the primordial root were immersed into the different tested concentrations of each dyes $(0.25 \%, 0.5 \%$ and $1 \%$ ) in three replicates, each one contained five bulbs and distilled water as a control. The exposure time of the onion bulbs in each experiment was 72 hours at $22^{\circ} \mathrm{C}$; they were protected against direct sunlight. In order to eliminate the influence of daylight rhythms, the plants were exposed to contain artificial light of middle intensity. When the root growth reached the length of 1 to $2 \mathrm{~cm}$ the tips were cut, fixed and preserved. The cut root tips were fixed in 1:3 aceticalcohols (Carnoy's fixative) for $24 \mathrm{~h}$ and then stored in $70 \%$ alcohol for future use. The bulbs grown in distilled water served the purpose of control. Conventional squash preparation was adopted following the acid hydrolysis of cellulosic cell wall in 
$1 \mathrm{~N} \mathrm{HCl}$ followed by warming at $60^{\circ} \mathrm{C}$. Staining was done in $2 \%$ acetic-carmine in $45 \%$ glacial acetic acid $(\mathrm{v} / \mathrm{v})$ followed by rubbing in rust free iron needle to visualize the targeted stages under microscope (Tartar et al., 2014 ).

The dry seeds of Vicia faba (Giza 2) were washed and then soaked (40) seeds in $0.25 \%, 0.5 \%$ and $1 \%$ concentrations of each dyes in 3 replicates and the control was soaked in distilled water for $24 \mathrm{~h}$, then they were folded with cotton cloth wetted with treatments and the germination was carried out at 20 ${ }^{\circ} \mathrm{C}$ in the dark. When the root growth reached the length of 1 to $2 \mathrm{~cm}$ the tips were cut, fixed and preserved. The cut root tips were fixed in 1:3 aceticalcohols (Carnoy's fixative) for $24 \mathrm{~h}$ and then stored in $70 \%$ alcohol for future use. The seeds grown in distilled water served the purpose of control. Conventional squash preparation was adopted following the acid hydrolysis of cellulosic cell wall in $1 \mathrm{~N} \mathrm{HCl}$ followed by warming at $60^{\circ} \mathrm{C}$. Staining was done in $2 \%$ acetic-carmine in $45 \%$ glacial acetic acid $(\mathrm{v} / \mathrm{v})$ followed by rubbing ) in rust free iron needle to visualize the scrabble stages under microscope ( Tartar et al., 2014).

Molecular studies:

Genomic DNA was extracted from the of Allium cepa and Vicia faba treated roots with the three food colorants for three days using a protocol described by Li et al. (2010). Genomic DNA was checked by electrophoresis using $1 \%$ agarose gel in $0.5 \mathrm{x}$ TBE (Tris-Borate-EDTA) buffer as mentioned by Sambrook et al. (1989). Genomic DNA was analyzed with RAPD-PCR technique. Table (1) shows, the five primers which were used for screening the genomic DNA and its sequences. The used primers have 10base long oligonucleotides of arbitrary sequence. The PCR reaction mixtures were prepared $(25 \mu \mathrm{l}$ total volumes). Amplifications were carried out as follow: Pre-denaturation, $95^{\circ} \mathrm{C}$ for $5 \mathrm{~min}$. Then 40 cycles of denaturation at $94^{\circ} \mathrm{C}$ for $0.30 \mathrm{~min}$., annealing at $36^{\circ}$ $\mathrm{C}$ for $1 \mathrm{~min}$., and extension at $72^{\circ} \mathrm{C}$ for $2 \mathrm{~min}$. Followed by post-extension at $72^{\circ} \mathrm{C}$ for $5 \mathrm{~min}$ and hold at $4^{0} \mathrm{C}$ forever. PCR products were analyzed by electrophoresis using $1.2 \%$ agarose gel in $1 \mathrm{X}$ TAE buffer, stained with $0.3 \mathrm{mg} / \mathrm{ml}$ ethidium bromide. DNA ladder was used to determine band size. Bands were detected under U.V light. The polymorphic bands detected in each treated sample and compared with the number of bands detected in the control.

Table 1. The nucleotide sequence and the GC content of the primers used for the RAPD-PCR

\begin{tabular}{ll}
\hline Primer & Sequence \\
\hline OPA2 & 5'-TGCCGAGCTG-3' \\
OPY5 & 5'-GGCTGCGACA-3' \\
OPZ1 & 5'-TCTGTGCCAC-3' \\
OPA10 & 5'-GTGATCGCAG-3' \\
OPC18 & 5'-TGGGGGACTC-3' \\
\hline
\end{tabular}

Statistical analysis:
The mitotic index (MI) was calculated as (Number of dividing cells / Total number of cells scored) x 100. Similarly, the mitotic depression (M.D) was calculated as (MI (Control)-MI (Treated) / MI (Control) $\}$ x 100. Cytological analysis were calculated in a Randomized Complete Block Design with three replicates. Obtained data were expressed as means \pm standard error (SE). The data were subjected to OneWay Analysis of Variance; statistical package for social sciences (SPSS) software for windows version 20, followed by LSD test to compare the significance of differences between means. The results were considered significant at $\mathrm{P}<0.05$.

\section{Results and Discussion}

This study was conducted in the cytological and molecular genetics lab, Genetic Department, Faculty of Agriculture, Minia University. The experiments were carried out to estimate the genotoxic effects of three food colorants (Ponceau 4R, Sunset yellow and Tartrazin) with different concentrations $(0.25 \%$, $0.50 \%$ and $1.00 \% \mathrm{w} / \mathrm{v}$ ) on two plant species s Allium cepa $L$ as monocot plant and Vicia faba as dicot plant. It has been shown that there are a number of higher plants such as Vicia faba, Hordium vulgare, and A. cepa can be used in the study of the cytogenetic and mutagenesis effect of chemicals (Sang and Li, 2004; and Türkoğlu, 2009).

\section{Effects on the cytological feature of Allium cepa L.:}

A. cepa has been used to evaluate DNA damage, such as chromosome aberrations and disturbances in the mitotic cycle. It is characterized as a low-cost test. It is easily handled and has advantages over other short-term tests system. A. сера has been indicated as an efficient system for the evaluation of the cytotoxicity due to their kinetic properties of proliferation and its small number $(2 n=16)$ of chromosomes and other features, which facilitates their analysis for the detection of damage to the structure of the DNA molecule and changes in the cell division index (mitotic index) (Gomes et al., 2013) .

The present study showed that the cytogenetic effects of three food colorants on the root Meristem cells of $A$. серa, with an aim to provide information that authenticate the genotoxicity potential of these colorants. In the present work, allium bulbs were mitotically analyzed (mitotic index) about 3000 to 4000 cells were examined from each treatment to detect mutagenic activity of three food colorants. The effects on the percentage of rooted bulbs, MI and frequency of mitotic phases are given in (Table 2 and Fig. 1) for the treatments with Ponceau $4 R$, Sunset yellow and Tartrazine respectively.

\section{Mitotic Index and Mitotic Depression:}

Data in Table (2) show the mean values of Mitotic index (MI) of Allium bulbs treated with different 
concentrations of three food colorants (Ponceau 4R, Sunset yellow and Tartrazine). The statistical analysis showed that the differences in mitotic indices (MI) values of all treated bulbs were highly significantly comparing with MI value of the control. The mitotic indices for the treated cells ranged between $4.48 \pm 0.05$ $\%$ in the treatment with Ponceau4R (1\%) to $10.02 \pm 0.17 \%$ in the treatment with Ponceau 4R $(0.25 \%)$. The mitotic index of the control was $14.70 \pm$ $0.06 \%$

All colorants treatments reduced and depressed the mitotic indices and the reduction percentages were $31.83,40.00$ and $69.52 \%$ for the treatments of Ponceau $4 \mathrm{R}$ for the concentrations $0.25,0.50$ and $1.00 \%$ respectively. The reduction percentages for the Sunset yellow were $35.85,50.89$ and $64.87 \%$ for $0,25,0.50$ and the concentrations $1.0 \%$ respectively. Tartrazin treatments reduced the mitotic indices by $31.91,50.75$ and $66.73 \%$ for the concentrations 0.25 .0 .50 and $1.00 \%$ respectively. In the present work mitotic index was calculated as a percentage of dividing cells of ' bulbs root tip which they were treated with the different concentrations of the three food colorants. The estimated MI value in all treatments was significantly lower than the control and this result was obtained herein is in agreement with Dönbak, et a.l(2002) who stated that the food colorants decreased the mitotic index (MI) in Allium cepa.

\section{3. Percentages of Mitotic Stage:}

Regarding to the mitotic phases of the treated bulbs root tips, the microscopic study revealed that the percentages of prophase cells were ranging from $33.64 \pm 2.14$ for Sunset yellow $1.00 \%$ to $66.24 \pm 5.12$ for Ponceau $4 \mathrm{R} 0.25 \%$. In the control cells the prophase percentage was $68.85 \pm 5.52$. The data in Table (2) and Fig.(1) also show that the percentage of prophase cells have decreased by increasing the concentration of the colorants used. The statistical analysis showed that the difference between all treatments and control were significant. On the other hand, the percentage of metaphase cells in Tartrazine $1.00 \%(19.00 \pm 2.90)$ and $0.5 \%(15.00 \pm 2.29)$ were higher than the control (13.21 \pm 2.02$)$ but Ponceau 4R $1 \%(4.98 \pm 0.76)$ was significantly the lowest one. Table (2) also shows that the percentages of all treatments were significantly higher than the control in anaphase (9.68 \pm 1.48$)$ and telophase $(8.25 \pm 1.26)$ index. The results in Table (2) showed a correlation between the increasing of metaphase cell percentages and increasing of food colorants concentration. The differences between the means of treatments were significant. Studying some cytological criteria such as mitotic index (MI), chromosome behavior during cell cycle are considered to be an important indication of genetic stability in Allium. The mitotic index was extensively studied in allium and other species of family alliaceae and many other organisms to evaluate genotoxicity, cytotoxicity, rate of growth, cell cycle and/or the cytological stability (Carita and MarinMorales, 2008; and Seth et al., 2008).
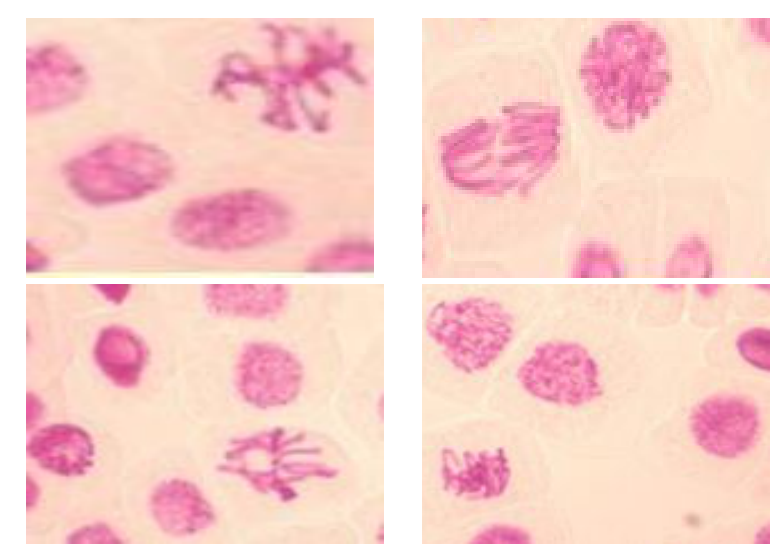

Fig (1).The Mitotic phases in the root tip cells of Vicia faba treated with different food dyes concentrations.

Table 2. The mitotic indices and the percentages of mitotic phases in the root tip cells of Allium cepa treated with three concentrations of the three food colorants (Mean $\pm \mathrm{SE}$ ).

\begin{tabular}{|c|c|c|c|c|c|c|c|c|c|}
\hline $\begin{array}{l}\text { Treme } \\
\text { nts }\end{array}$ & $\begin{array}{l}\% \text { Co } \\
\text { nc. } \\
\text { w/v }\end{array}$ & $\begin{array}{l}\text { No. of } \\
\text { cells } \\
\text { examin } \\
\text { ed }\end{array}$ & $\begin{array}{l}\text { No. of } \\
\text { dividing } \\
\text { cells }\end{array}$ & $\begin{array}{l}\text { \% Prop } \\
\text { hase }\end{array}$ & $\begin{array}{l}\% \text { Meta } \\
\text { phase }\end{array}$ & $\begin{array}{l}\text { \%Anap } \\
\text { hase }\end{array}$ & $\begin{array}{l}\text { \% Telop } \\
\text { hase }\end{array}$ & MI & $\begin{array}{l}\% \\
\text { Mitotic } \\
\text { Depress } \\
\text { ion }\end{array}$ \\
\hline Control & & 3189 & 468.78 & $\begin{array}{l}68.85 \pm 5 \\
.52\end{array}$ & $\begin{array}{l}13.21 \pm 2 \\
.02\end{array}$ & $\begin{array}{l}9.68 \pm 1 . \\
48\end{array}$ & $\begin{array}{l}8.25 \pm 1 . \\
26\end{array}$ & $\begin{array}{l}14.70 \pm 2 \\
.25\end{array}$ & $0 \pm 0$ \\
\hline $\begin{array}{l}\text { Poncea } \\
\text { u 4R }\end{array}$ & 0.25 & 3954 & 396.19 & $\begin{array}{l}66.24 \pm 5 \\
.12\end{array}$ & $\begin{array}{l}10.34 \pm 1 \\
.58\end{array}$ & $\begin{array}{l}14.08 \pm 2 \\
.15\end{array}$ & $\begin{array}{l}9.34 \pm 1 \\
43\end{array}$ & $\begin{array}{l}10.02 \pm 1 \\
.53\end{array}$ & $\begin{array}{l}31.83 \pm 4 \\
86\end{array}$ \\
\hline
\end{tabular}




\begin{tabular}{|c|c|c|c|c|c|c|c|c|c|}
\hline & 1.00 & 3280 & 315.67 & $\begin{array}{l}55.54 \pm 4 \\
.48 \\
57.23 \pm 4 \\
.74\end{array}$ & $\begin{array}{l}11.15 \pm 1 \\
.70 \\
4.98 \pm 0 . \\
76\end{array}$ & $\begin{array}{l}19.15 \pm 2 \\
.93 \\
26.89 \pm 2 \\
.11\end{array}$ & $\begin{array}{l}14.16 \pm 2 \\
.16 \\
10.90 \pm 1 \\
.67\end{array}$ & $\begin{array}{l}8.82 \pm 1 . \\
35 \\
4.48 \pm 0 . \\
68\end{array}$ & $\begin{array}{l}40.00 \pm 6 . \\
11 \\
69.52 \pm 1 \\
0.62\end{array}$ \\
\hline \multirow{3}{*}{$\begin{array}{l}\text { Sunset } \\
\text { yellow }\end{array}$} & 0.25 & 3880 & 365.88 & $\begin{array}{l}43.63 \pm 3 \\
66\end{array}$ & $\begin{array}{l}8.69 \pm 1 . \\
33\end{array}$ & $34.73 \pm 2$ & $12.95 \pm 1$ & $9.43 \pm 1$. & $\begin{array}{l}35.85 \pm 5 . \\
48\end{array}$ \\
\hline & 0.50 & 3518 & 254.00 & $\begin{array}{l}36.31 \pm 2 \\
.55\end{array}$ & $\begin{array}{l}10.55 \pm 1 \\
.61\end{array}$ & $\begin{array}{l}29.04 \pm 2 \\
.44\end{array}$ & $\begin{array}{l}24.10 \pm 1 \\
.68\end{array}$ & $\begin{array}{l}7.22 \pm 1 . \\
10\end{array}$ & $\begin{array}{l}50.89 \pm 7 \\
77\end{array}$ \\
\hline & 1.00 & 3027 & 156.50 & $\begin{array}{l}33.64 \pm 2 \\
.14\end{array}$ & $\begin{array}{l}12.27 \pm 1 \\
.87\end{array}$ & $\begin{array}{l}22.05 \pm 1 \\
.37\end{array}$ & $\begin{array}{l}32.05 \pm 2 \\
.90\end{array}$ & $\begin{array}{l}5.17 \pm 0 . \\
79\end{array}$ & $\begin{array}{l}64.87 \pm 9 \\
91\end{array}$ \\
\hline \multirow{3}{*}{$\begin{array}{l}\text { Tartraz } \\
\text { in }\end{array}$} & 0.25 & 3914 & 391.79 & $\begin{array}{l}56.51 \pm 4 \\
.63\end{array}$ & $\begin{array}{l}9.70 \pm 1 . \\
48\end{array}$ & $\begin{array}{l}20.47 \pm 2 \\
.13\end{array}$ & $\begin{array}{l}13.32 \pm 1 \\
.03\end{array}$ & $\begin{array}{l}10.01 \pm 1 \\
.53\end{array}$ & $\begin{array}{l}31.91 \pm 4 . \\
87\end{array}$ \\
\hline & 0.50 & 3664 & 265.27 & $\begin{array}{l}49.95 \pm 3 \\
.63\end{array}$ & $\begin{array}{l}15.00 \pm 2 \\
.29\end{array}$ & $\begin{array}{l}15.96 \pm 1 \\
.44\end{array}$ & $\begin{array}{l}19.09 \pm 1 \\
.92\end{array}$ & $\begin{array}{l}7.24 \pm 1 . \\
11\end{array}$ & $\begin{array}{l}50.75 \pm 7 \\
75\end{array}$ \\
\hline & 1.00 & 2980 & 145.72 & $\begin{array}{l}41.14 \pm 3 \\
.28\end{array}$ & $\begin{array}{l}19.00 \pm 2 \\
.90\end{array}$ & $\begin{array}{l}19.36 \pm 1 \\
.96\end{array}$ & $\begin{array}{l}20.50 \pm 1 \\
.13\end{array}$ & $\begin{array}{l}4.89 \pm 0 . \\
75\end{array}$ & $\begin{array}{l}66.73 \pm 1 \\
0.19\end{array}$ \\
\hline LSD $_{0.05}$ & \multicolumn{2}{|c|}{2.351} & 0.542 & 1.00 & \multicolumn{2}{|r|}{0.80} & 0.39 & \multicolumn{2}{|c|}{2.19} \\
\hline LSD $_{0.01}$ & \multicolumn{2}{|c|}{3.207} & 0.740 & 1.37 & & 1.10 & 0.54 & \multicolumn{2}{|c|}{2.99} \\
\hline
\end{tabular}

\section{2. Effect on the cytological feature of Vicia faba:}

The laboratory experiment was carried out to estimate the cytotoxicity effects of three synthetic food colorants on Vicia faba plants. The mitotic index were measured in root tips cells from samples treated with the three concentrations of each colorant as well as for the control (samples treated with distilled water).

\section{2. 2. Mitotic Index and Mitotic Depression :}

The results of the microscopic examination of the mitotic cells of Vicia faba root tips germinated in different concentrations of the three food colorants and control are given in Table (3) and Fig.2. The mitotic index in the control was $11.9 \pm 1.22$ while it ranged in all colorant treatments from $0.98 \pm 0.15$ for Tartrazin $1.00 \%$ to $4.74 \pm 0.91$ for Sunset Yellow $0.25 \%$. The differences between the treatments were significant regarding to the depression of mitotic indices. The data in Table (3) showed that 3000 to 4000 cells were examined for each treatment and the mitotic indices decreased when the concentration of the colorant increased. The depressions of mitotic indices in all treatments have ranged from $60.16 \%$ (Sunset Yellow 0.25\%) to $91.76 \%$ (Tartrazine $1.00 \%$ ). The highest reduction in mitotic index was achieved when the beans were treated with Tartrazine $1.00 \%$.

\section{2. 3. Percentages of Mitotic Stage:}

Data in Table (3)and Fig. (2) showed that the percentages of prophase cells have ranged from $45.88 \pm 2.92$ (Tartrazin $1.00 \%$ ) to $84.64 \pm 6.84$ (Sunset yellow $0.50 \%)$. The percentage of prophase cells has different from colorant to another and also affected with concentration of colorant. All differences were significant comparing with the control. The percentages of prophase cells are the highest percentages compared with other phases of the divided cells. Regarding to the percentage of metaphase cells, it is clear from data in Table (3) that these percentages have ranged from $\mathbf{4 . 5 4} \pm \mathbf{1 . 8 8}$ (Sunset yellow 0.25\%) to 19.78 \pm 1.86 (Tartrazine $\mathbf{1 . 0 0 \%}$ ). the treated root tips with Tartrazine $1.00 \%$ showed the highest percentage of metaphase cells.

For anaphase, the percentages of cells in this phase have ranged from $1.60 \pm 0.25$ (Sunset yellow $1.00 \%$ ) to $24.02 \pm 2.87$ (Tartrazine $1.00 \%$ ). The percentages of telophase cells have ranged from $5.24 \pm 0.23$ (Sunset yellow $0.50 \%$ ) to $21.17 \pm 1.26$ (Tartrazine $0.50 \%$ ). From these results, it is clear that the Tartrazine colorant has the strongest effect on metaphase and anaphase while the sunset yellow has the lowest effect. Table (3) also show that the percentages of all treatments the cell at anaphase were lower than the control $(13.28 \pm 1.16)$ except Ponceau 4R 1\% (17.84 \pm 0.71$)$ and Tartrazine 1\% (24.02 \pm 2.87$)$ was significantly higher than the control. Also, the percentages of all treatments at telophase were lower than the control $(21.54 \pm 1.64)$. The food colorants caused a change in the frequencies of different mitotic stages. The mitotic cells phase's ratios varied according to the concentration and type of food colorant used in the different treatment, with a large number of the cells at prophase and the lowest number of cells at anaphase. It is clear from the data illustrated in (Tables 3) that the Mitotic index decreased according to the increase in the concentration of treatment for all tested colorants. This reduction was more intense in Tartrazine than the other colorants.

The One- way ANOVA results of the Mitotic Index of food dyes colorants showed that the means of the Mitotic Index at all concentrations were significantly different $(\mathrm{p}<0.001)$ from the means of the control. The Allium cepa and Vicia faba test has 
been widely used throughout the world to detect mutagenic activity of food colorants (Rencüzoğulları et al., 2001; Türkoğlu, 2007, 2009). MI frequencies decreased with increasing concentrations of food colorants. The present findings are in agreement with earlier studies on other food additives demonstrating mitotic inhibition in root Meristem cells of A. cepa Due to the reduced number of dividing cells, it is suggested that these chemicals might have a mitototic depressive effect on the cell division of $A$. cepa and $V$. faba. Mitototic depression blocks the synthesis of DNA and nuclear proteins (Schulze and Kirschner, 1986). According to Brunori (1971), disturbance of interphase stage at S or G2 could occur through subphase inhibition or an increase in phase duration. From the results in Tables $\mathbf{2}$ and 3, it was noted that the rate of each of the mitotic stages in A. cepa and Vicia faba was affected by the treatments. Generally, the increase in prophase percentage and the simultaneous decrease in the metaphase and anaphase-telophase percentages were counted by exposing them to these chemicals. Similar results have been reported after the treatment of A. cepa and Vicia faba root tip cells with various other food additives (Türkoğlu, 2007and 2009).
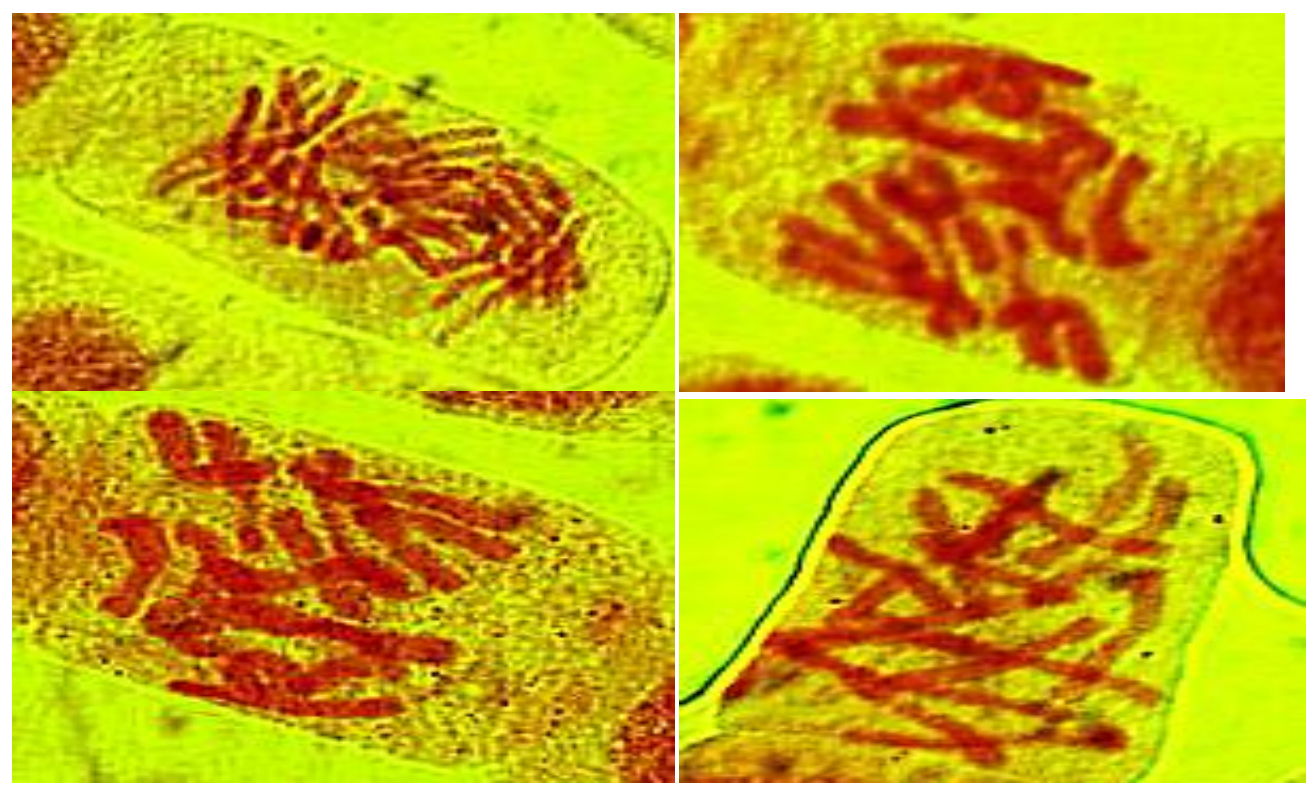

Fig (2).The Mitotic phases in the root tip cells of Allium cepa treated with different food dyes concentrations.

Table 3. The mitotic indices and the percentages of mitotic phases in the root tip cells of Vicia faba treated with three concentrations of three food colorants (Mean $\pm \mathrm{SE}$ ).

\begin{tabular}{|c|c|c|c|c|c|c|c|c|c|}
\hline Treatments & $\begin{array}{l}\text { \% Conc. } \\
\text { g/l }\end{array}$ & $\begin{array}{c}\text { Total No. } \\
\text { of cells }\end{array}$ & $\begin{array}{c}\text { No. of } \\
\text { dividing } \\
\text { cells }\end{array}$ & $\begin{array}{c}\text { \%Prophas } \\
\text { e }\end{array}$ & $\begin{array}{c}\text { \% Metapha } \\
\text { se }\end{array}$ & $\begin{array}{c}\text { \%Anaphas } \\
\text { e }\end{array}$ & $\begin{array}{c}\text { \% Telophas } \\
\text { e }\end{array}$ & MI & $\begin{array}{c}\text { \% Mitotic } \\
\text { Depression }\end{array}$ \\
\hline Control & & 3836 & 456.48 & $54.32 \pm 2.47$ & $10.86 \pm 1.11$ & $13.28 \pm 1.16$ & $21.54 \pm 2.64$ & $11.9 \pm 1.82$ & $\mathbf{0} \pm \mathbf{0}$ \\
\hline Ponceau 4R & $\begin{array}{l}0.25 \\
0.50 \\
1.00 \\
\end{array}$ & $\begin{array}{l}3443 \\
4180 \\
3438 \\
\end{array}$ & $\begin{array}{l}101.16 \\
87.45 \\
47.44 \\
\end{array}$ & $\begin{array}{l}70.44 \pm 6.28 \\
66.36 \pm 6.59 \\
64.76 \pm 6.94 \\
\end{array}$ & $\begin{array}{l}7.36 \pm 1.19 \\
6.60 \pm 0.78 \\
4.72 \pm 0.72 \\
\end{array}$ & $\begin{array}{l}10.20 \pm 1.10 \\
11.20 \pm 1.14 \\
17.84 \pm 1.71 \\
\end{array}$ & $\begin{array}{l}7.59 \pm 1.22 \\
15.84 \pm 1.69 \\
12.69 \pm 1.80 \\
\end{array}$ & $\begin{array}{l}2.54 \pm 0.39 \\
2.42 \pm 0.37 \\
1.38 \pm 0.21 \\
\end{array}$ & $\begin{array}{l}78.66 \pm 6.02 \\
79.63 \pm 6.16 \\
88.40 \pm 6.50 \\
\end{array}$ \\
\hline $\begin{array}{l}\text { Sunset } \\
\text { yellow }\end{array}$ & $\begin{array}{l}0.25 \\
0.50 \\
1.00 \\
\end{array}$ & $\begin{array}{l}3270 \\
3416 \\
3181 \\
\end{array}$ & $\begin{array}{l}155.00 \\
107.95 \\
67.44 \\
\end{array}$ & $\begin{array}{l}77.04 \pm 5.91 \\
84.64 \pm 6.84 \\
82.69 \pm 7.25 \\
\end{array}$ & $\begin{array}{l}4.54 \pm 1.88 \\
5.86 \pm 1.48 \\
5.45 \pm 1.24 \\
\end{array}$ & $\begin{array}{l}7.75 \pm 1.34 \\
4.26 \pm 0.11 \\
1.60 \pm 0.25 \\
\end{array}$ & $\begin{array}{l}10.68 \pm 0.52 \\
5.24 \pm 0.23 \\
5.50 \pm 053 \\
\end{array}$ & $\begin{array}{l}4.74 \pm 0.72 \\
3.16 \pm 0.48 \\
2.12 \pm 0.32 \\
\end{array}$ & $\begin{array}{l}60.16 \pm 4.19 \\
63.45 \pm 4.69 \\
82.19 \pm 6.55 \\
\end{array}$ \\
\hline Tartrazin & $\begin{array}{l}0.25 \\
0.50 \\
1.00 \\
\end{array}$ & $\begin{array}{l}3294 \\
4044 \\
3925 \\
\end{array}$ & $\begin{array}{l}81.69 \\
47.72 \\
38.47 \\
\end{array}$ & $\begin{array}{l}65.99 \pm 3.1 \\
58.69 \pm 3.19 \\
45.88 \pm 2.92 \\
\end{array}$ & $\begin{array}{l}8.5 \pm 0.54 \\
9.82 \pm 1.48 \\
19.78 \pm 1.86 \\
\end{array}$ & $\begin{array}{l}9.52 \pm 0.39 \\
10.32 \pm 1.21 \\
24.02 \pm 2.87\end{array}$ & $\begin{array}{l}16.99 \pm 1.17 \\
21.17 \pm 1.26 \\
10.32 \pm 032\end{array}$ & $\begin{array}{l}2.48 \pm 0.38 \\
1.18 \pm 0.18 \\
0.98 \pm 0.15\end{array}$ & $\begin{array}{r}79.16 \pm 6.09 \\
90.08 \pm 7.76 \\
91.76 \pm 7.02 \\
\end{array}$ \\
\hline LSD $_{0.05}$ & 1.37 & & 0.61 & 0.71 & \multicolumn{2}{|c|}{0.79} & 0.20 & \multicolumn{2}{|l|}{3.42} \\
\hline LSD $_{0.01}$ & 1.84 & & 0.82 & 0.95 & \multicolumn{2}{|c|}{1.06} & 0.28 & \multicolumn{2}{|l|}{4.66} \\
\hline
\end{tabular}

\section{Molecular studies:}

The RAPD assay is an efficient procedure for screening nucleotide sequence polymorphism among individuals as each primer will direct the amplification of several discrete loci within a genome Samal et.al (2003). As primers modified by even a single nucleotide produce different banding profiles, the RAPD technique can generate polymorphism between very closely-related genotypes (Deng et. al (1995). Results of the present work showed that the percentage of polymorphism of these five primers diverted in effects on onions and beans as in Table (4) 
and Table (5) respectively.RAPD markers were used for evaluating genetic diversity in Allium cepa revealed different levels of polymorphism between treatments. The sequence of primer (OPC-18) was the highest percentage of polymorphism in onion bulbs treated with three food colorants. The sequence of primer (OPA-10) was the highest percentage of polymorphism in broad beans treated with three food colors. The polymorphism percentages were varied according to the effect of food colors on the plant genome and the type of primer. It was ranged from 25,00 to $72,72 \%$ in Allium cepa genome Table (4) while the it was ranged from 00,00 to 100 in the genome of Vicia faba Table (5).

Table 4. Gel Polymorphism of PCR fragments generated by five RAPD primers in allium bulbs treated with three food colors.

\begin{tabular}{|c|c|c|c|c|c|c|}
\hline \multirow{2}{*}{$\begin{array}{l}\text { APD } \\
\text { primers } \\
\text { name }\end{array}$} & \multirow{2}{*}{$\begin{array}{l}\text { Monomorphic } \\
\text { bands }\end{array}$} & \multirow{2}{*}{$\begin{array}{l}\text { Unique } \\
\text { bands }\end{array}$} & \multicolumn{2}{|c|}{ Polymorphic bands } & \multirow{2}{*}{$\begin{array}{l}\text { Total } \\
\text { number } \\
\text { bands }\end{array}$} & \multirow[b]{2}{*}{$\begin{array}{l}\text { Polymorphism } \\
\text { (\%) }\end{array}$} \\
\hline & & & $\begin{array}{l}\text { without } \\
\text { Unique }\end{array}$ & with Unique & & \\
\hline OPA2 & 6 & 1 & 2 & 3 & 9 & 33.33 \\
\hline OPY5 & 6 & 1 & 1 & 2 & 8 & 25.00 \\
\hline OPZ1 & 5 & 4 & 1 & 5 & 10 & 50,00 \\
\hline OPA10 & 4 & 2 & 1 & 3 & 7 & 42.86 \\
\hline OPC18 & 3 & 3 & 5 & 8 & 11 & 72.72 \\
\hline Mean & 4.8 & 2.2 & 2 & 4.2 & 9 & 44.78 \\
\hline
\end{tabular}

Table 5. Gel Polymorphism of PCR fragments generated by five RAPD primers in broad beans treated with three

\begin{tabular}{|c|c|c|c|c|c|c|}
\hline $\begin{array}{l}\text { RAPD } \\
\text { primers } \\
\text { name } \\
\end{array}$ & $\begin{array}{l}\text { Monomorphic } \\
\text { bands }\end{array}$ & $\begin{array}{l}\text { Unique } \\
\text { bands }\end{array}$ & $\begin{array}{l}\text { Polymor } \\
\text { without } \\
\text { Unique } \\
\end{array}$ & $\begin{array}{l}\text { bands } \\
\text { with Unique }\end{array}$ & $\begin{array}{l}\text { Total } \\
\text { number of } \\
\text { bands }\end{array}$ & $\begin{array}{l}\text { Polymorphism } \\
(\%)\end{array}$ \\
\hline OPA2 & 8 & $\overline{\mathbf{0}}$ & $\mathbf{0}$ & 0 & 8 & 00,00 \\
\hline OPY5 & 6 & 0 & 1 & 1 & 7 & 14.29 \\
\hline OPZ1 & 6 & 2 & $\mathbf{0}$ & 2 & 8 & 25.00 \\
\hline OPA10 & 0 & 1 & 5 & 6 & 6 & 100,00 \\
\hline OPC18 & 1 & $\mathbf{0}$ & 6 & 6 & 7 & 85.70 \\
\hline Mean & 4.2 & 0.6 & 2.4 & 3 & 7.2 & 45,00 \\
\hline
\end{tabular}

Generally, all of the primers which have been used in the present work revealed significant variation between treatments. Changes in RAPD patterns as loss of normal bands and appearance of new bands compared with control. It is apparent that the main changes observed in the RAPD profiles have resulted both in the appearance or disappearance of different bands. These effects may be correlated with structural rearrangements in DNA caused by different types of DNA damages (Becerril, et. al, 2002). Appearance of new bands can be explained as the result of DNA structural changes (breaks, transpositions, deletions, etc.) Atienzar, et. al ( 2001). In the same way, cell populations exposed in vitro to genotoxins suffer DNA alterations in a certain number of cells, which are reflected as variations in the fingerprint obtained for the control population. These are defined as band losses and/or gains as well as alterations in the intensity of amplification of some of them. Such alterations in vivo are considered mutations that are produced by changes to, deletions of or insertions into the pair bases Atienzar et. al (2001) and Danylchenko and Sorochinsky ( 2005).

These different types of DNA damages must be detected by changes in RAPD profiles. Food colors have been reported as a well-known mutagenic and clastogenic agent. Previous studies suggested food color as one of the best known chemical mutates as it reacts with the bimolecular including DNA and damage their structure and biological activity (Das and Mukherjee, 2004). The result obtained in this work was in accordance with previous studies on the same plant-test Macioszek and Kononowize (2004). One objective of this study was to evaluate the potential of the RAPD method to detect DNA effects of food colors in Vicia faba. RAPD profiles detect alterations to genomic DNA through the use of arbitrarily primed PCR reactions. In the present study, variation in band intensity, disappearance of bands, and appearance of new PCR products occurred in profiles generated from the treated seedlings. Food colors -induced DNA damage, may significantly interfere with the PCR events. It has been reported that such structural changes are likely to have a significant effect on the kinetics of PCR events De Wolfe, et. al (2004). New PCR products can be amplified because some sites become accessible to the primers after structural change or because the same mutations have occurred in the genome. Amongst the new bands observed in the exposed cells, bands B2-3 and B3-7, were detected for most of the treatments. This leads one to think that these bands are the result of a food color-directed action on specific points on the 
genomic DNA. This is in accordance with the study of

( Selvi, et. al 2007 and Liu,.et. al 2008).

(B)
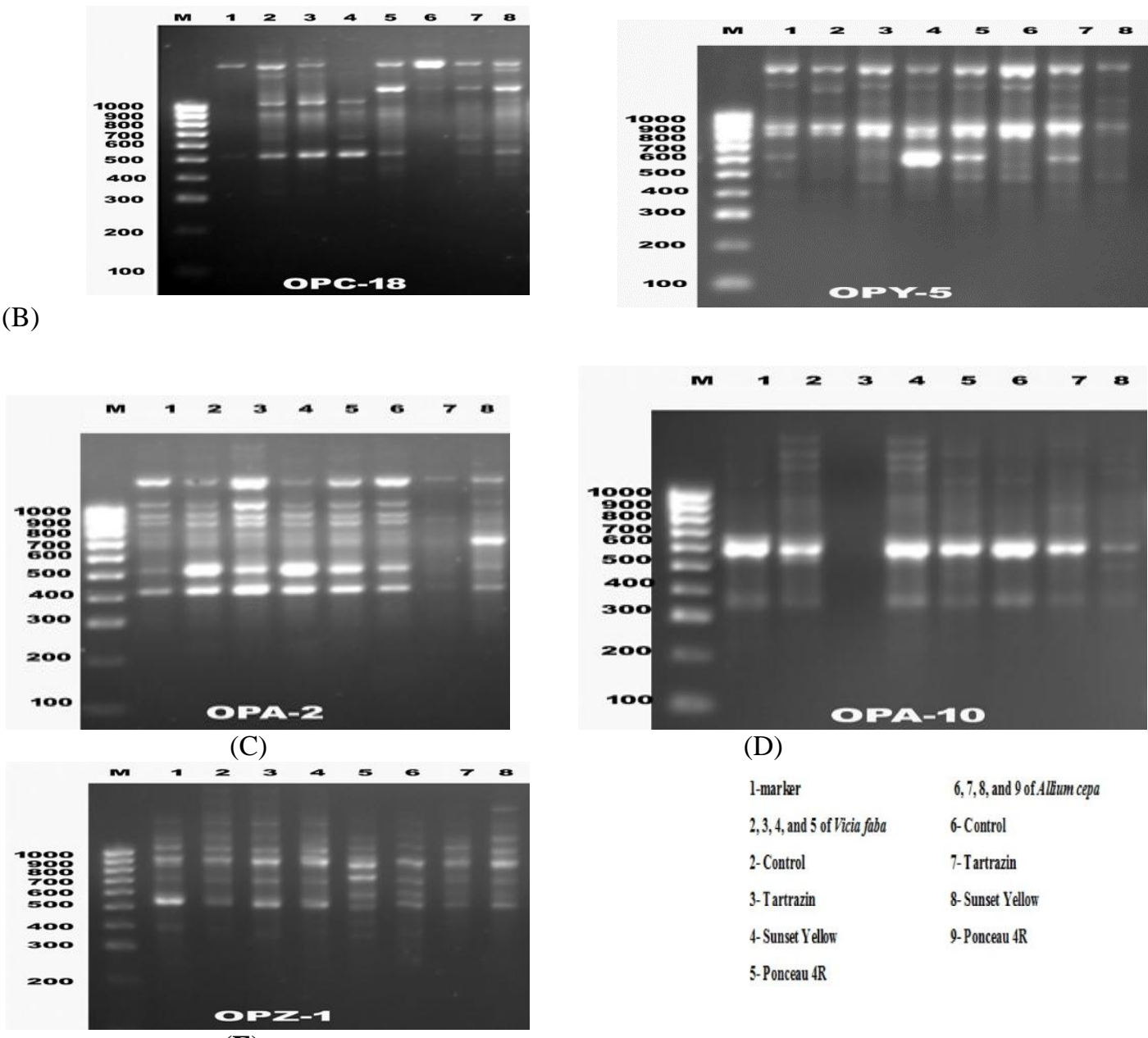

(D)

$\begin{array}{ll}\text { 1-marker } & 6,7,8, \text { and 9 of Allium cepa } \\ \text { 2,3,4, and 5 of Vicia faba } & \text { 6-Control } \\ \text { 2-Control } & \text { 7-Tartrain } \\ \text { 3-Tartrazin } & \text { 8-Sunset Yellow } \\ \text { 4-Sunset Yellow } & \text { 9-Ponceau 4R } \\ \text { 5-Ponceau 4R } & \end{array}$

(E)

Fig. (3). RAPD profiles of the roots Allium cepa and Vicia faba seedlings treated with Ponceau 4R, Sunset yellow and Tartrazin, were generated using five primers.

\section{Reference}

Abbey, J.; Fields, B.; O'Mullane, M. and L. D. Tomaska (2013). Food Additives: Colorants. Encyclopedia of Food Safety, 459-465.

Abdelmigid,H.M.(2009).Risk Assessment of Food Coloring Agents on DNA Damage Using RAPD Markers.The Open BiotechnologyJournal;3:96102

Adhvaryu, S. G. and V.C. Shah (1979). In vitro studies on effects of mitomycin-C on cell division, cell cycle and chromosomes of $\mathrm{CHO}$ cells. The Nucleus 22 (3): 196- 204.

Atienzar, F. A.; Cheung, V. V.; Jha, A. N. and M. H. Depledge (2001). Fitness parameters and DNA effects are sensitive indicators of copper induced toxicity in Daphnia magna. Toxicol. Sci. 59: 241-250.

Becerril, C.; Ferrero, M.; Sanz, F. and A. Castano (2002). Detection by RAPD of genetic alterations in vitro: amplification and conservation conditions of DNA extracts. Toxicol Mech Methods; 12(2): 155-67.
Bolle, P.; Mastrangelo, S.; Tucci, P. and M. G. Evandri (2004). Clastogenicity of atrazine assessed with the Allium cepa test. Environmental andMolecularMutagenesis;43(2): 137-141.

Brunori, A. (1971). Synthesis of DNA and mitosis in relation to cell differentiation in the roots of Vicia faba and Lacuta sativa. Caryologia 24: 209-215.

Carita and Marin-Morales (2008). Induction of chromosome aberrations in the Allium cepa test system caused by the exposure of seeds to industrial effluents contaminated with azo dyes; 72(5):722-5.

Danylchenko, O. and B. Sorochinsky (2005). Use of RAPD assay for the detection of mutation changes in plant DNA induced by UV-B and $\gamma$ rays. BMC Plant Biology, 5(Suppl 1),S9.

Das, A. and A. Mukherjee (2004). Genotoxicity testing of the food colors, amaranth and degradation kinetic of tulip flower anthocyanin. Food and Chemical;14(8):1594-602.

Deng, Z. M.; Gentile, A.; Nicolosi, E.; Domina, F.; Vardi, E. and A. Tribulato (1995). Identification 
of in vivo and in vitro lemon mutants by RAPD markers. - J. hort. Sci., 70: 117-125.

De Wolfe, H.; Blust, R. and T. Backeljau (2004). The use of RAPD in ecotoxicology. Mutation Res; 566(3): 249-62.

Dönbak, L.; Rencüzoğulları, E. and M. Topaktaş (2002). The cytogenetic effects of the food additive boric acid in Allium cepa L. Cytologia 67: 153-157.

FDA (December 2009). Color Additive Status List.

FDA (November 9, 2008). Food and Drug Administration Compliance Program Guidance Manual, Chapter 03 - Food borne Biological Hazards p37.

Feng, J.; Cerniglia, C. E. and H. Chen (2012). "Toxicological significance of azo dye metabolism by human intestinal microbiota," Frontiers in Bioscience (Elite Edition), 4(2):568586.

Gomes, K. M.; Oliveira, M. V.; Carvalho, F. R.; Menezes, C. C. and A. P. Peron (2013). Cytotoxicity of food dyes sunset yellow (E-110), bordeaux red (E-123), and tatrazine yellow (E102) on Allium cepa L. root meristematic cells. Food Sci Technol (Campinas); 33: 218-223.

Gömürgen, A. N. (2005) Cytological effect of the potassium metabisulphite and potassium nitrate food preservative on root tips of Allium cepa $\mathrm{L}$. Cytologia 70: 119-128.

Grant, W. F. (1999). Higher plant assays for the detection of chromosomal aberrations and gene mutations - a brief historical background on their use for screening and monitoring environmental chemicals. Mutation Res., 426: 107-112.

Hashem, M. M.; Atta, A. H.; Arbid, M. S.; Nada, S. A.; Mouneir, S. M. and G. F. Asaad (2011).Toxicological impact of amaranth, sunset yellow and curcumin as food coloring agents in albino Rats. Journal of Pakistan Medical Students; 1(2): 43- 51. Ilhan, D. and C. Aki (2010). Mutagenicity of sunset yellow and brilliant black in Vicia faba L. and Allium cepa L Fresenius Environmental Bulletin 19(5):769-772.

Kaushik, G. C. (1996). Cytotoxicity of cement kiln dust on mitosis of roof tip cells in Vicia faba. J Ecotoxico Environ Monit; 6(1): 53-57.

Kumar, G. and N. Srivastava (2011). Genotoxic effects of two commonly used food additives of boric acid and sunset yellow in root Meristems of Trigonella foenum-graecum, Iranian Journal of Environmental Health Science \& Engineering, vol. 8, no. 4, pp. 361-366.

Liu, W.; Yang, Y. S.; Li, P. J.; Zhou, Q. X.; Xie, L. J. and Y. P. Han (2008). Risk assessment of cadmium contaminated soil on plant DNA damage using RAPD and physiological indices.J.Hazard.Mater,161(2-3): 878-883.

Macioszek, V. K. and A. K. Kononowicz (2004). The Evaluation of the Genotoxicity of Two commonly used Food Colors: Quinoline Yellow
(E 104) And Brilliant Black Bn (E 151). Cellular \& Molecular Biology Letters; 9, 107 - 122.

Matsumoto, S. T.; Mantovani, M. S.; Malaguttii, M. I. A.; Dias, A. L.; Fonseca, I. C. and M. A. Marin-Morales (2006). Genotoxicity and mutagenicity of water contaminated with tannery effluents, as evaluated by the micronucleus test and comet assay using the fish Oreochromis niloticus and chromosome aberrations in onion root-tips Genetics and Molecular Biology, 29, 1, 148-158

Montaser, M. M. and M. E. Alkafafy (2013). Effects of Synthetic Food Colour (Carmoisine) on Expression of Some Fuel Metabolism Genes in Liver of Male Albino Rats. Life Science Journal; 10(2): 2191-2198.

Odeigah, P. G. C.; Nurudeen, O. and O. O. Amund (1997b). Genotoxicity of oil field wastewater in Nigeria. Heredities, 126: 161-167.

Patra, M. and A. Sharma (2002). Relative efficacy of Allium cepa and Allium sativum in anaphasetelophase test screening metal genotoxicity. Biologia 57:409-414.

Rencuzogullari, E.; Kayraldiz, A.; Ila, H. B.; Çakma, T. and M. Topaktas (2001). The Cytogenetic Effects of Sodium Metabisulfite, a Food Preservative in Root Tip Cells of A. cepa .Turk J Biol.; 25: 361-370.

Samal, S.; Rout, G. R.; Nayak, S.; Nanda, R. M.; Lenka, P. C. and S. Das (2003). Primer screening and optimization for RAPD analysis of cashew. Biol. Plant. 46: 301-304.

Sambrook, J.; Fritsch, E. F. and T. Maniatis (1989). Gel Electrophoresis of DNA. In: Sambrook, J., Fritsch, E.F. and Maniatis, T., Eds., Molecular Cloning: A Laboratory Manual, Chapter 6, Cold Spring Harbor Laboratory Press, Cold Spring Harbor, New York.

Sang, N. and G. K. Li (2004). Genotoxicity of municipal landfill leachate on root tips of Vicia faba. Mutation Research; 560: 159-165

Schulze, E. and S. Kirschner (1986). Microtubule dynamics in interphase cells. Journal of Cell Biology 102: 1020-1031.

Selvi, B. S.; Ponnuswami, V. and T. Sumathi (2007). Identification of DNA Polymorphism induced by Gamma Ray Irradiation in Amla (Emblica Officinalis Gaertn.) Grafts of V M and V M Generation. J Appl Sci Res; 3(12): 1933-5.

Seth, C. S.; Misra, V.; Chauhan, L. K. S. and R. R. Singh (2008). Genotoxicity of cadmium on root Meristem cells of A.cepa: cytogenetic and Comet assay approach.Ecotoxicology and Environmental Safety, 71(3), 711-716.

Tartar, G.; Kaymak, F.; Fulya, D. and G. Muranli (2014). Genotoxic Effects of Avenoxan on $A$. cepa L. and A. sativum L. Caryologia; 59(3): 241247.

Türkoğlu, Ş. (2007). Genotoxicity of five food preservatives tested on root tips of Allium cepa $\mathrm{L}$. 
Mutation Research Genetic Toxicology and Environmental Mutagenesis 626: 4-14.

Turkoglu, S. (2009). Genotoxic effects of mono-, di, and trisodium phosphate on mitotic activity,
DNA content, and nuclear volume in Allium cepa L. Carylogia; 62(3): 171-179.

Wood, R. M. (2004). Analytical methods for food additives. Boca Raton: CRC Press. 48(7): 2853 2857.

\section{DNA- تقييم مخاطر التأثيرات السمية الوراثية للملونات الغذائية الصناعية على جذور الفول والبصل باستخدام بصمة RAPD

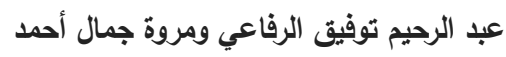 \\ قسم الوراثة ، كلية الزراعة ، جامعة المنيا}

الاختبارات الحيوية النباتية ذات حساسية عاليه وبسيطة مقارنة بالاختبارت الحيويه الحيوانيه لتقييم السمية الوراثية للمركبات الكيميائيه. تم

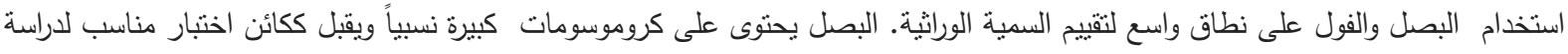
الطفرات البيئية. كما تم استخدام الفول لتحديد الثأثير الجيني للأصباغ الاصطناعية المستخدمة كإضافات غذائية. مؤشر الانقسام الميتوزى هو واحد

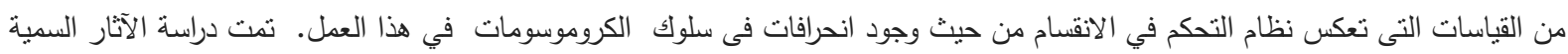

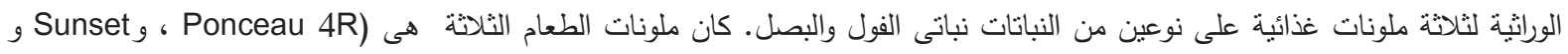

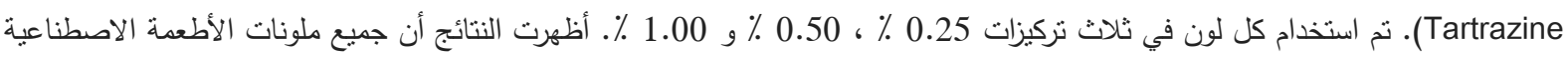

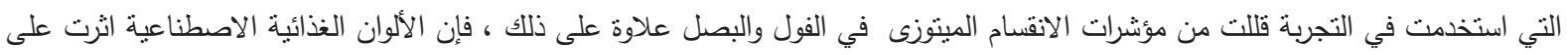

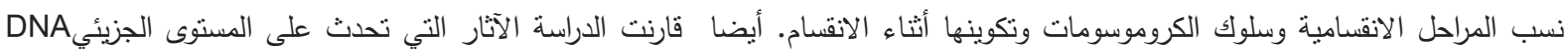

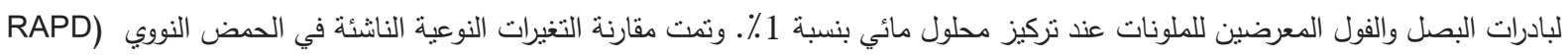

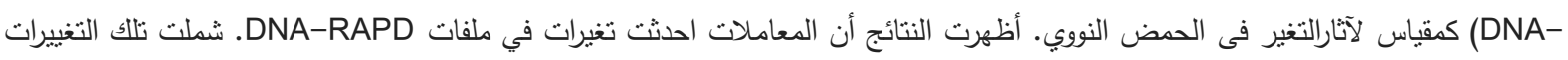

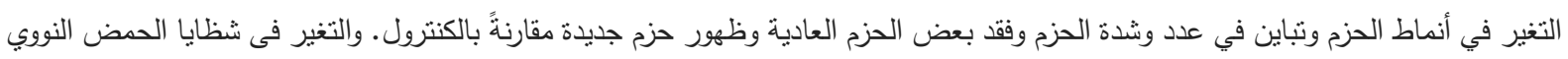
يختلف من جينوم إلى أخرى. 